\title{
Pengaruh Pendidikan Kesehatan Melalui Klinik VCT Terhadap Pengetahuan Remaja Tentang HIV/AIDS Di Kecamatan Aikmel Lombok Timur
}

\author{
${ }^{1}$ Eka Yuni Hariyawanti, ${ }^{2}$ Lalu Sulaiman, ${ }^{3}$ Sabar Setiawan \\ ${ }^{12}$ Program Studi Magister Administrasi dan Kebijakan Kesehatan Universitas Qamarul Huda \\ Badaruddin \\ Email : ekayunihariyawanti@gamil.com
}

\begin{abstract}
Abstrak. Masa remaja adalah periode transisi dari masa anak-anak menuju masa dewasa, dimana terjadi perubahan fisik, biologis, dan psikologis. Permasalahan kesehatan pada remaja telah menjadi prioritas masalah kesehatan masyarakat di berbagai negara. HIV/AIDS merupakan salah satu isu utama kesehatan reproduksi dan seksual pada remaja. Salah satu upaya pemerintah untuk terus menekan angka kejadian HIV/AIDS adalah dengan melakukan promosi dan pendidikan kesehatan reproduksi khususnya HIV/AIDS. Penelitian ini bertujuan untuk mengetahui pengaruh pendidikan kesehatan terhadap tingkat pengetahuan remaja tentang HIV/AIDS di Kecamatan Aikmel, Lombok Timur. Penelitian kuasi dengan rancangan pretest-postest dilakukan terhadap 30 remaja di Klinik VCT Puskesmas Kecamatan Aikmel. Observasi dilakukan sebanyak dua kali, yaitu sebelum dan setelah diberikan pendidikan kesehatan dengan memberikan kuesioner lalu mengukur tingkat pengetahuan tentang HIV/AIDS. Intervensi berupa pendidikan kesehatan diberikan melalui metode ceramah dan media poster. Tingkat pengetahuan sebelum dan setelah intervensi dianalisis menggunakan paired t-test. Terdapat pengaruh pemberian pendidikan kesehatan terhadap tingkat pengetahuan remaja tentang HIV/AIDS di Kecamatan Aikmel ( $p$ value $<0,05)$. Pendidikan kesehatan yang tepat perlu diterapkan di lingkungan keluarga dan pendidikan agar remaja memperoleh informasi yang tepat mengenai kesehatan seksual dan reproduksi
\end{abstract}

Keyword: Pendidikan Kesehatan, Remaja, Kesehatan Reproduksi

\section{PENDAHULAUN}

\section{Latar Belakang}

Masa remaja adalah periode transisi dari masa anak-anak menuju masa dewasa, dimana terjadi perubahan fisik, biologis, dan psikologis. World Health Organization (WHO) mengklasifikasikan batasan usia remaja adalah 10-19 tahun, sedangkan Badan Kependudukan dan Keluarga Berencana (BKKBN) mendefinisikan remaja sebagai individu yang belum menikah dengan rentang usia 10-24 tahun. (BKKBN, 2017; WHO, 2014).

Populasi remaja yang tinggi, sekitar seperlima dari total penduduk dunia, tentu membutuhkan perhatian khusus. Remaja yang sehat akan membantu meningkatkan status kesehatan masyarakat karena kesehatan remaja, terutama perempuan memiliki efek intergenerasi (Naswa \& Marfatia, 2010). Oleh karena itu, permasalahan kesehatan pada remaja menjadi prioritas masalah kesehatan masyarakat di berbagai negara. Seks bebas, kehamilan yang tidak diinginkan, aborsi, penularan penyakit menular seksual (PMS), dan HIV/AIDS menjadi isu utama kesehatan reproduksi dan seksual pada remaja. (Kusmiran, 2014; Umaroh, Kusumawati, \& Kasjono, 2015).

Badan Pusat Statistik (BPS) melaporkan, pada tahun 2017 terdapat 67,36 juta remaja (25\% total penduduk Indonesia) dan $66,5 \%$ nya pernah melakukan hubungan seksual pranikah. Sebanyak 20,7\% penduduk Indonesia berusia 15-24 tahun terdeteksi positif HIV dari total 43.800 kasus HIV yang dilaporkan pada tahun 2017. Kasus HIV/AIDS di Lombok Timur sendiri pada tahun 2016 adalah sebanyak 20 kasus (BPS, 2017; BPS NTB, 2017).

Salah satu upaya pemerintah untuk terus menekan angka kejadian HIV/AIDS adalah dengan melakukan promosi dan pendidikan 
Jurnal Ilmu Sosial dan Pendidikan

http://ejournal.mandalanursa.org/index.php/JISIP/index

Terakreditasi Peringkat 5 (No. SK: 85/M/KPT/2020)

kesehatan reproduksi khususnya HIV/AIDS. Surveilans Terpadu Biologis dan Perilaku (STBP) tahun 2015 menyebutkan remaja sebagai salah satu kelompok rentan HIV/AIDS memiliki tingkat pengetahuan yang masih rendah terkait HIV/AIDS (Kemenkes RI, 2016). Hasil studi pendahuluan terhadap 20 remaja di Kecamatan Aikmel melalui teknik wawancara menunjukkan bahwa sebesar $60 \%$ remaja memiliki pengetahuan kesehatan terkait HIV/AIDS yang rendah. Rendahnya tingkat pengetahuan remaja terkait HIV/AIDS semakin menegaskan pentingnya pendidikan kesehatan reproduksi dan seksual remaja baik secara formal maupun non-formal. Pemberian pendidikan kesehatan yang tepat dapat memicu perubahan sikap dan perilaku positif dalam kaitannya menekan kejadian HIV/AIDS (Jones et al, 2013).

Penelitian ini bertujuan untuk mengetahui apakah intervensi pendidikan kesehatan tentang HIV/AIDS dapat meningkatkan pengetahuan tentang HIV/AIDS pada remaja di Kecamatan Aikmel, Lombok Timur dengan membandingkan tingkat pengetahuan remaja sebelum dan setelah intervensi.

\section{METODE}

Penelitian ini merupakan penelitian kuasi dengan rancangan pretest-posttest. Penelitian dilakukan di klinik VCT Puskesmas AIkmel terhadap 30 remaja di Kecamatan Aikmel. Observasi dilakukan sebanyak dua kali, yaitu sebelum dan setelah diberikan pendidikan kesehatan. Observasi pertama dilakukan untuk mengetahui dan mengukur tingkat pengetahuan remaja tentang HIV/AIDS sebelum intervensi melalui pemberian kuesioner. Intervensi berupa pemberian pendidikan kesehatan terkait HIV/AIDS mencakup pengertian, cara penularan, dan bahaya atau dampak HIV/AIDS. Pemberian pendidikan kesehatan dilakukan dengan metode ceramah dan media poster. Setelah intervensi, tingkat pengetahuan remaja diukur kembali untuk mengetahui pengaruh intervensi.

Jurnal Ilmu Sosial dan Pendidikan
Vol. 4. No. 4 November 2020

p-ISSN: 2598-9944 e- ISSN: 2656-6753

Analisis data dalam penelitian ini meliputi analisis univariat dan bivariat. Analisis univariat dilakukan untuk mendeskripsikan tingkat pengetahuan remaja sebelum intervensi. Analisis bivariat dilakukan untuk mengetahui pengaruh pendidikan kesehatan terhadap pengetahuan remaja sebelum dan sesudah intervensi menggunakan paired t-test. Nilai signifikansi $(p$-value $)<0,05$ menunjukkan adanya pengaruh pendidikan kesehatan terhadap tingkat pengetahuan remaja tentang HIV/AIDS.

\section{HASIL}

\section{Pengaruh Pendidikan Kesehatan terhadap Pengetahuan tentang HIV/AIDS}

Tabel 1 menyajikan data tingkat pengetahuan remaja terkait HIV/AIDS sebelum dan setelah pemberian pendidikan kesehatan untuk melihat pengaruhnya terhadap tingkat pengetahuan remaja.

Tabel 1. Pengaruh Pendidikan Kesehatan terhadap Pengetahuan tentang HIV/AIDS

\begin{tabular}{|l|c|c|c|c|}
\hline $\begin{array}{c}\text { Tingkat } \\
\text { Pengetahuan }\end{array}$ & $\mathbf{n}$ & Mean & SD & $\boldsymbol{p}$-value \\
\hline $\begin{array}{l}\text { Sebelum } \\
\text { intervensi }\end{array}$ & 30 & 12,70 & 2,292 & 0,000 \\
\hline $\begin{array}{l}\text { Setelah } \\
\text { intervensi }\end{array}$ & 30 & 24,80 & 2,058 & \\
\hline
\end{tabular}

Rerata pengetahuan remaja mengalami peningkatan signifikan setelah intervensi $(\mathrm{p}<0,05)$. Hal ini menunjukkan bahwa terdapat pengaruh pemberian pendidikan kesehatan terhadap pengetahuan remaja tentang HIV/AIDS.

\section{PEMBAHASAN}

Tingkat pengetahuan remaja tentang HIV/AIDS di Kecamatan Aikmel, Lombok Timur tergolong rendah. Pengetahuan remaja tentang HIV/AIDS yang rendah sering dikaitkan dengan rendahnya informasi yang tepat dan mudah diakses oleh remaja mengenai HIV/AIDS. Orangtua dan guru sebenarnya merupakan sumber informasi kesehatan seksual dan reproduksi yang ideal bagi remaja (Jones et al., 2013). Namun, kentalnya adat dan budaya timur yang menganggap perilaku seksual 
Jurnal Ilmu Sosial dan Pendidikan

http://ejournal.mandalanursa.org/index.php/JISIP/index

Terakreditasi Peringkat 5 (No. SK: 85/M/KPT/2020)

pranikah adalah sesuatu yang tabu, membuat orangtua dan/atau guru tidak merasa nyaman dalam memberikan edukasi kesehatan seksual dan reproduksi seperti penggunaan kondom, perilaku seksual, serta HIV/AIDS dan PMS (Jones et al., 2013; Manaf et al., 2014). Hal ini menyebabkan remaja mencari sumber informasi lain yang belum tentu benar dan tepat secara medis, sehingga cenderung menimbulkan kesalahan presepsi dan perilaku seksual (Lee et al, 2015).

Setelah dilakukan intervensi berupa pemberian edukasi, terdapat perbedaan pengetahuan remaja tentang HIV/AIDS antara sebelum dan setelah intervensi. Pengetahuan remaja mengalami peningkatan signifikan. Sejalan dengan penelitian ini, berbagai penelitian lain menyebutkan bahwa remaja yang diberi edukasi kesehatan memiliki pengetahuan tentang HIV /AIDS, self-awareness, dan perilaku seksual yang lebih baik dibandingkan remaja yang tidak diberi edukasi kesehatan (Jones, 2013; Alavi-Arjas, 2018).

Pendidikan kesehatan dapat dimulai dari lingkup terkecil, yaitu keluarga. Pendidikan kesehatan juga dapat diterapkan kedalam kurikulum pendidikan formal (Sommert \& Sota, 2013; Sani et al., 2016; Alavi-Arjas, 2018). Hal ini dapat mencegah remaja mengakses informasi kesehatan seksual dan reproduksi dari sumber yang kurang tepat dan menyebakan perilaku seksual berisiko (Arisjulyanto, 2019).

\section{KESIMPULAN}

Terdapat pengaruh pemberian pendidikan kesehatan terhadap pengetahuan remaja tentang HIV/AIDS di Kecamatan Aikmel, Lomobok Timur. Hasil penelitian ini semakin menegaskan pentingnya edukasi kesehatan yang tepat baik secara formal maupun non formal. Penelitian selanjutnya untuk mengetahui pengaruh pendidikan kesehatan terhadap pengetahuan remaja tentang HIV/AIDS dapat dilakukan dengan sampel yang lebih besar dan mengontrol variabel luar yang diamati dalam selang waktu yang lebih lama sehingga hubungan kausal dapat
Vol. 4. No. 4 November 2020

p-ISSN: 2598-9944 e- ISSN: 2656-6753

diketahui dengan baik hingga tahap perubahan sikap dan perilaku.

\section{DAFTAR PUSTAKA}

Alavi-Arjas, F., Farnam, F., Granmayeh, M., Haghani, H. (2017). The effect of sexual and reproductive health education on knowledge and selfefficacy of school conselors. Journal of Adolescents Health, 1-6.

Arisjulyanto, D., Ismail, D., \& Fuad, A. (2019). Intensity Of Social Media Use With Premarital Sexual Behavior Of Adolescents In Smk 2 Gerung West Lombok. Universitas Gadjah Mada.

Badan Kependudukan dan Keluarga Berencana Nasional (BKKBN). (2012). Adolescent and Youth: Status, Challenges and Programmes. Indonesia Country Report. Jakarta, Indonesia: BKKBN.

BPS. (2017). Survey Data Penduduk Indonesia Tahun 2017. Jakarta.

BPS NTB. (2017). Jumlah kasus HIV/AIDS menurut kabupaten/kota di Provinsi NTB, 2016. Diakses 1 September 2020 dari

https://ntb.bps.go.id/statictable/2017/1 1/16/195/jumlah-kasus-hiv-dan-aidsmenurut-kabupaten-kota-di-provinsinusa-tenggara-barat-2016.html.

Jones, V., Modeste, N., Marshak, H. H., Fox, C. (2013). The Effffect of HIV/AIDS Education on Adolescents in Trinidad and Tobago. ISRN Infectious Disease, 1-8.

Kementerian Kesehatan RI. (2015). Survei Terpadu Biologis dan Terpadu. Jakarta, Indonesia: Kemenkes.

Kusmiran, E. (2014). Kesehatan Reproduksi Remaja dan Wanita. Jakarta: Salembajh Medika.

Lee, Y-M., Florez, E., Tariman, J., McCarter, S., Riesche, L. (2015). Factors related to sexual behaviour and sexual education programs for Asian-American 


\section{Terakreditasi Peringkat 5 (No. SK: 85/M/KPT/2020)}

adolescents. Applied Nursing Research , 28 (3), 222-228.

Manaf, M. R. A., Tahir, M. M., Sidi, H., Midin, M., Jaafar, N. R. N., Das, S., Malek, A. M. A. (2014). Pre-marital sex and its predicting factors among Malaysian youths. Comprehensive Psychiatry , 55 (SUPPL. 1), S82 - S88.

Naswa, S., Marfatia, Y. S. (2010). Adolescent HIV/AIDS: Issues and chalenge. Indian Journal Sexually Transmitted Diseases and AIDS, 31, 1-10.

Sani, A.S., Abraham, C., Denford, S., Ball, S. (2016). School-based sexual health education interventions to prevent STI/HIV in subSaharan Africa: a systematic review and meta-analysis. BMC Public Health, 16, 1-26.

Sommart, J. \& Sota, C. (2013). The effectiveness of a school-based sexual health education program for junior high school students in Khon Kaen, Thailand. Procedia Social and Behaviour Sciences, 91, 208-214.

Umaroh, A. K., Kusumawati, Y., \& Kasjono, H. S. (2015). Hubungan antara faktor internal dan eksternal dengan perilaku seksual pranikah remaja indonesia. Jurnal Kesehatan Masyarakat Andalas, $10,65-75$.

World Health Organization. (2020). Adolescents Health. Diakses 1 September 2020, dari https://www.who.int/healthtopics/adolescent-health\#tab=tab_1. 